Article

\title{
Synthesis and Crystal Structures of Benzimidazole-2-thione Derivatives by Alkylation Reactions
}

\author{
El Sayed H. El Ashry ${ }^{1, *,+}$, Yeldez El Kilany ${ }^{1,2,+}$, Nariman M. Nahas ${ }^{2,+}{ }^{+}$Assem Barakat ${ }^{1,3, \dagger}$, \\ Nadia Al-Qurashi ${ }^{2, \dagger}$, Hazem A. Ghabbour ${ }^{4,+}$ and Hoong-Kun Fun ${ }^{4,+}$ \\ Received: 9 November 2015 ; Accepted: 1 December 2015 ; Published: 22 December 2015 \\ Academic Editor: Derek J. McPhee \\ 1 Chemistry Department, Faculty of Science, Alexandria University, P. O. Box 426, Alexandria 21321, Egypt; \\ yeldez244@hotmail.com (Y.E.K.); ambarakat@ksu.edu.sa (A.B.) \\ 2 Chemistry Department, Faculty of Applied Science, Umm Al-Qura University, Makkah 21955, Saudi Arabia; \\ narinahas@hotmail.com (N.M.N.); maam10@hotmail.com (N.A.-Q.) \\ 3 Department of Chemistry, College of Science, King Saud University, P. O. Box 2455, Riyadh 11451, \\ Saudi Arabia \\ 4 Department of Pharmaceutical Chemistry, College of Pharmacy, King Saud University, P. O. Box 2457, \\ Riyadh 11451, Saudi Arabia; ghabbourh@yahoo.com (H.A.G.); hfun.c@ksu.edu.sa (H.-K.F.) \\ * Correspondence: eelashry60@hotmail.com; Tel.: +20-122-743-0924 \\ + These authors contributed equally to this work.
}

\begin{abstract}
Alkylated, benzylated and bromoalkylated benzimidazole-thione that intramolecularly heterocyclized to 3,4-dihydro-2H-[1,3]thiazino[3,2-a]benzimidazole were synthesized. The chemical structure of the synthesized product was characterized by Infra Red, ${ }^{1} \mathrm{H}-\mathrm{NMR},{ }^{13} \mathrm{C}-\mathrm{NMR}$, and Mass spectroscopy. Furthermore, the molecular structures of $\mathbf{8}$ and $\mathbf{9}$ were confirmed by $\mathrm{X}$-ray single crystallography in different space groups, $\mathrm{Pbca}$ and $\mathrm{P} 2_{1} / c$, respectively.
\end{abstract}

Keywords: benzimidazole-thione; thiazino[3,2-a]benzimidazole; X-ray

\section{Introduction}

Benzimidazole is a biologically important scaffold and it is a useful structural motif for the development of molecules of pharmaceutical or biological interest. Appropriately substituted benzimidazole derivatives have found diverse therapeutic applications. It has earned an important place as a pharmacophore in chemotherapeutic agents of pharmacological activities. The biological significance of benzimidazoles can be correlated with its close relationship with the structure of purines that have vital role in the biological system. Moreover, 5,6-dimethyl-1( $\alpha$-D-ribofuranosyl)benzimidazole is an integral part of the structure of Vitamin B12. Different pharmacological effects, including antifungal [1], anthelmintic [2], anti-HIV [3], antihistaminic [4-6], antiulcer [7,8], cardiotonic [9], antihypertensive [10,11], and neuroleptic [12], have been reported. The optimization of benzimidazole-based structures has resulted in various drugs that are currently on the market, such as omeprazole (proton pump inhibitor), pimobendan (ionodilator), and mebendazole (anthelmintic).

Having the above aspects in mind, our attention has been attracted to synthesizing benzimidazolethione ring and its $\mathrm{N}$-acetyl derivative to study their alkylation, aralkylation and bromoalkylation, which subsequently underwent intramolecular cyclisation to give the fused tricyclic ring 3,4-dihydro- $2 H$-[1,3]thiazino[3,2-a]benzimidazole. The X-ray crystallographic analysis of the alkylated derivatives was also investigated. 


\section{Results}

\subsection{Chemistry}

Diversified methods for the preparation of $1 H$-benzo[ $d]$ imidazole-2(3H)-thione $\mathbf{1}$ have been reported [13-15], which can exhibit tautomerism of the type thione-thiol. Its ${ }^{1} \mathrm{H}-\mathrm{NMR}$ spectrum showed the presence of $2 \mathrm{NH}$ as a singlet at $\delta 12.20 \mathrm{ppm}$, which disappeared upon addition of $\mathrm{D}_{2} \mathrm{O}$. The protons of the phenyl ring showed two sets of signals at $\delta 7.19$ and $7.10 \mathrm{ppm}$. Thus, it existed in the thione form. Its reported [16] X-ray also agreed with the thione tautomer. The minimized energy structure agreed with that of the X-ray, which has been repeated and found to be similar to that reported earlier.

The reaction of $1 H$-benzo[d]imidazole-2(3H)-thione $\mathbf{1}$ with boiling acetic anhydride gave 1-(2-thioxo-2,3-dihydro-1H-benzo[ $d]$ imidazol-1-yl)ethanone 2 (Scheme 1). The product was similar to that prepared in literature [17]. The structure was confirmed from the spectral characteristics. Its IR spectrum showed the presence of broad signal at $1716(\mathrm{C}=\mathrm{O})$ and $3450 \mathrm{~cm}^{-1}(\mathrm{NH})$. Its ${ }^{1} \mathrm{H}-\mathrm{NMR}$ spectrum showed the presence of $\mathrm{CH}_{3}$ as a singlet at $\delta 1.92 \mathrm{ppm}$, the signal of $\mathrm{NH}$ disappeared because the sample was measured in a solvent mixture including $\mathrm{D}_{2} \mathrm{O}$. Its ${ }^{13} \mathrm{C}-\mathrm{NMR}$ spectrum showed the presence of $\mathrm{CH}_{3}$ as a singlet at $\delta 27.1 \mathrm{ppm}$, the $\mathrm{C}=\mathrm{O}$ as a singlet at $\delta 171.1 \mathrm{ppm}$ and $\mathrm{C}=\mathrm{S}$ as a singlet at $\delta 168.9$ ppm.<smiles>Sc1nc2ccccc2[nH]1</smiles>

1<smiles>S=c1[nH]c2ccccc2[nH]1</smiles>

$\mathbf{1}^{\prime}$<smiles>CC(=O)n1c(=S)[nH]c2ccccc21</smiles>

2

Scheme 1. Synthesis of 1-(2-thioxo-2,3-dihydro-1H-benzo[d]imidazol-1-yl)ethanone 2.

Attempted alkylation of $\mathbf{1}$ and $\mathbf{2}$ in presence of base gave the same alkylated products, indicating the loss of the acetyl group during the alkylation. Thus, reaction of 1-(2-thioxo2,3-dihydro-1H-benzo[d]imidazol-1-yl)ethanone 2 with different bases in acetone as a solvent gave $1 H$-benzo[d]imidazole-2(3H)-thione 1 whose rate of formation depend on the base and time. Piperidine was found to be the most efficient base for the deacetylation. This was followed by potassium hydroxide, triethylamine and then potassium carbonate. Hydrazine hydrate led to hydrolysis of the acetyl group without further reaction. These results confirmed that our conclusion of losing the acetyl group during the alkylation was due to the base present in the reaction medium.

Similarly, reaction of 5,6-Dimethyl-1H-benzo[ $d]$ imidazole-2(3H)-thione 3 with acetic anhydride gave a product that was identified as 1-(5,6-dimethyl-2-thioxo-2,3-dihydro- $1 H$-benzo[ $d]$ imidazol1-yl)ethanone 4 (Scheme 2). The chemical structure was deduced from the spectral analysis. IR spectrum showed the presence carbonyl amide at $1685 \mathrm{~cm}^{-1}$. Its ${ }^{1} \mathrm{H}-\mathrm{NMR}$ spectrum showed the presence of two $\mathrm{CH}_{3}$ as a singlet at $\delta 2.22 \mathrm{ppm}$ and $\mathrm{NH}$ as a singlet at $\delta 13.14 \mathrm{ppm}$. Its ${ }^{13} \mathrm{C}-\mathrm{NMR}$ spectrum showed the presence of two $\mathrm{CH}_{3}$ as two signals at $\delta 18.6$ and $18.9 \mathrm{ppm}$. The $\mathrm{C}=\mathrm{S}$ appeared as a signal at $168.4 \mathrm{ppm}$, and the $\mathrm{C}=\mathrm{O}$ as a signal at $171.1 \mathrm{ppm}$.<smiles>Cc1cc2[nH]c(=S)[nH]c2cc1C</smiles>

3

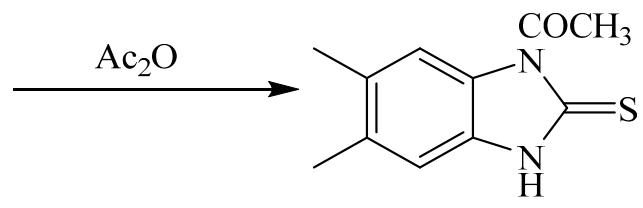

4

Scheme 2. 1-(5,6-Dimethyl-2-thioxo-2,3-dihydro-1H-benzo[d]imidazol-1-yl)ethanone 4. 
Reaction of 1-(5,6-dimethyl-2-thioxo-2,3-dihydro-1H-benzo[d]imidazol-1-yl)ethanone 4 in ethanol with hydrazine hydrate gave a crystalline product that was identified as 5,6-dimethyl- $1 H$ benzo[ $d$ ]imidazole-2(3H)-thione 3 but 1-(2-hydrazono-5,6-dimethyl-2,3- dihydro-1H-benzo[ $d]$ imidazol1-yl)ethanone did not form.

Reaction of $1 H$-benzo[ $d$ ]imidazole-2(3H)-thione 1 with ethyl bromoacetate, in presence of different bases in dry acetone gave ethyl 2-(1H-benzo[d]imidazol-2-ylthio)acetate 5 (Scheme 3). When using triethylamine as base, the product was obtained in high yield, but low yield was obtained when potassium carbonate was used [18]. The structure of the compound is consistent with the expected product. The IR data showed bands at $v 3457(\mathrm{NH}), 1739(\mathrm{C}=\mathrm{O}), 1269$, and $1167 \mathrm{~cm}^{-1}(\mathrm{C}-\mathrm{O})$. Its ${ }^{1} \mathrm{H}-\mathrm{NMR}$ spectrum showed the presence of one $\mathrm{NH}$ as a singlet at $\delta 12.60 \mathrm{ppm}$, the methylene group show one singlet at $\delta 4.18 \mathrm{ppm}$ connected with sulfur but not nitrogen. Its ${ }^{13} \mathrm{C}-\mathrm{NMR}$ spectrum showed the presence of one $\mathrm{CH}_{3}$ as a signal at $\delta 13.2$, two $\mathrm{CH}_{2}$ as a signal at $\delta 32.0$ and 60.4 ppm, and the presence of $\mathrm{C}=\mathrm{O}$ at $167.8 \mathrm{ppm}$.

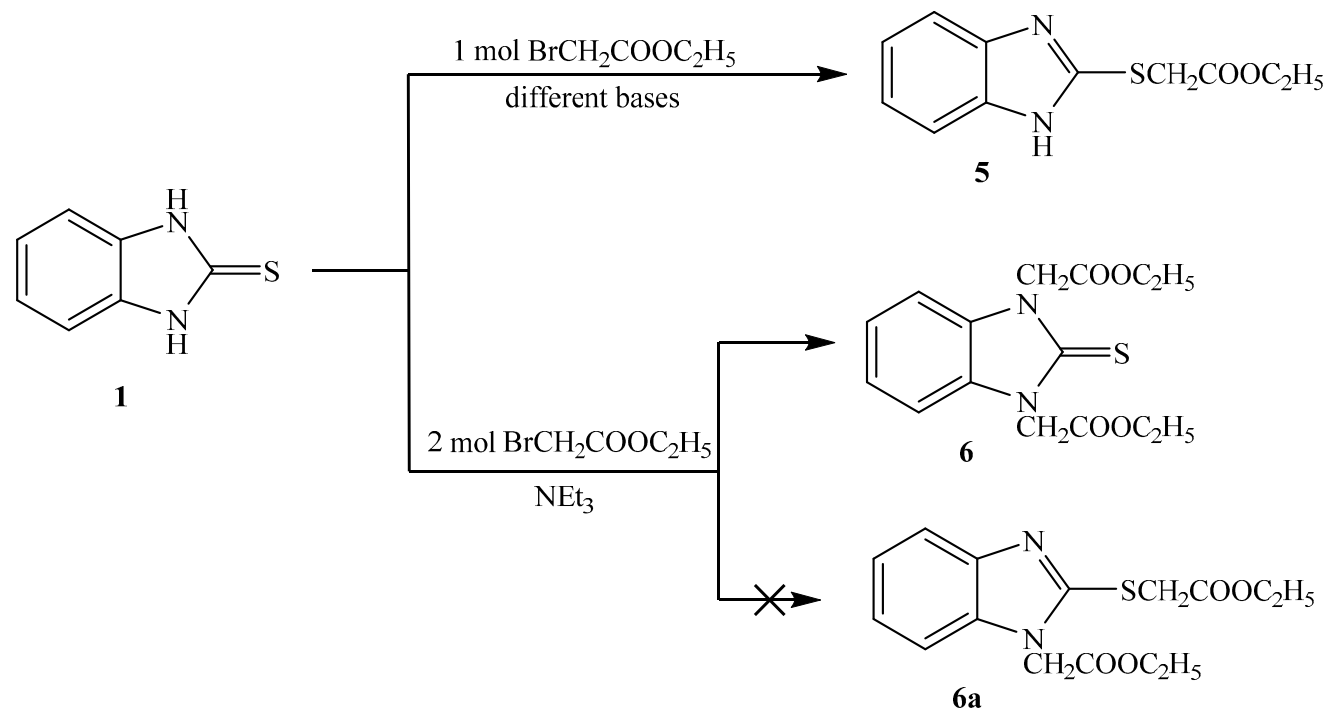

Scheme 3. Synthesis of 5 and 6.

It was found that reaction of 1 with two equivalents of ethylbromoacetate, in the presence of triethylamine in dry acetone gave diethyl 2,2'-(2-thioxo-1H-benzo[d]imidazole-1,3(2H)-diyl)diacetate 6. From spectral analysis, IR data showed bands at v: $1739(\mathrm{C}=\mathrm{O})$ and $1055 \mathrm{~cm}^{-1}(\mathrm{C}=\mathrm{S})$. Its ${ }^{1} \mathrm{H}-\mathrm{NMR}$ spectrum showed the presence of two methylene groups as one singlet at $\delta 5.16$ ppm connected with two nitrogens and indicated the absence of NH signals. This confirmed that the two methylene groups were attached to the two nitrogen atoms but not attached to sulfur and nitrogen. Its ${ }^{13} \mathrm{C}-\mathrm{NMR}$ showed the presence of two $\mathrm{CH}_{3}$ as signal at $\delta 13.10$, and two $\mathrm{CH}_{2}$ as signals at $\delta 44.00$ and $60.40 \mathrm{ppm}$. The ${ }^{13} \mathrm{C}$-NMR showed the presence of $\mathrm{C}=\mathrm{S}$ as signal at $\delta 166.20$ and $\mathrm{C}=\mathrm{O}$ as signal at $\delta 169.20 \mathrm{ppm}$

Reaction of 1-(2-mercapto-1H-benzo[d]imidazol-1-yl)ethanone 2 with 1-bromobutane in acetone as a solvent in the presence of triethylamine gave a product that was identified as 2-(butylthio)- $1 \mathrm{H}$ benzo[d]imidazole 8 (Scheme 4) [15]. Its IR spectrum showed the presence of a band at $\delta 3450 \mathrm{~cm}^{-1}$ (NH). Its ${ }^{1} \mathrm{H}-\mathrm{NMR}$ spectrum showed the presence of $\mathrm{NH}$ as a singlet at $\delta 12.47 \mathrm{ppm}$ and did not show the presence of a methyl group. Its ${ }^{13} \mathrm{C}-\mathrm{NMR}$ spectrum showed the presence of $\mathrm{CH}_{3}$ at $\delta 12.5$, and three sets of signals belong to $\mathrm{CH}_{2}$ at $\delta 20.3,29.9$ and $30.4 \mathrm{ppm}$. The compound 1-(2-(butylthio)-1H-benzo[d]imidazol-1-yl)ethanone 7 cannot be formed because the acetyl group was removed by base. The structure of 8 was confirmed by X-ray crystallography. The butyl group was found to exist in a zigzag conformation, as shown in Figure 1 which shows the Oak Ridge Thermal Ellipsoid Plot Program (ORTEP) for Crystal Structure. 

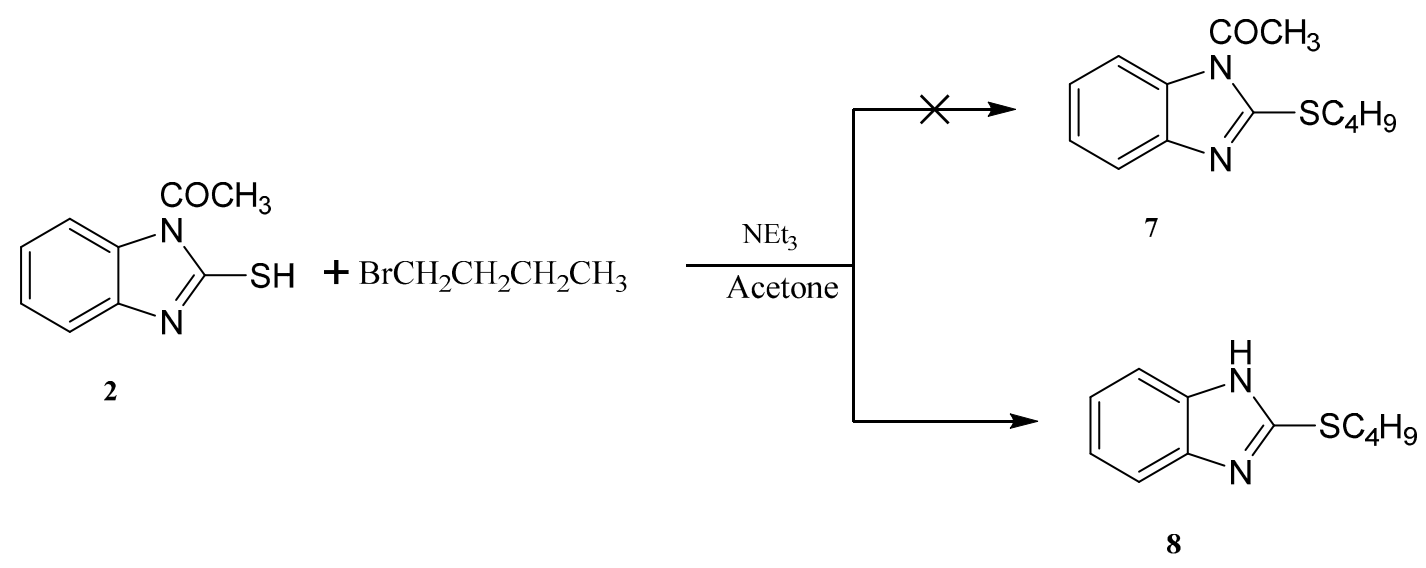

Scheme 4. Synthesis of the 2-(butylthio)-1H-benzo[d]imidazole 8.

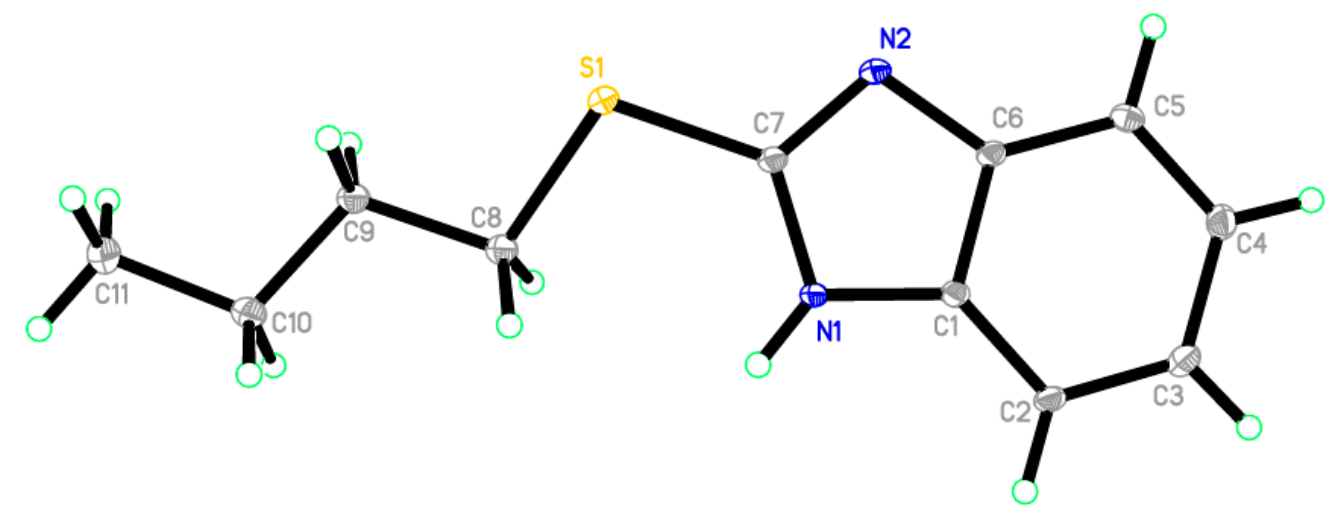

Figure 1. ORTEP diagram of the titled compound 8 drawn at $50 \%$ ellipsoids for non-hydrogen atom.

Reaction of $1 H$-benzo[ $d$ ] imidazole-2(3H)-thione 1 with dibromopropane, in ethanol as solvent and in the presence of triethylamine gave 3,4-dihydro-2H-[1,3]thiazino[3,2-a]benzimidazole 9 and not the 1,3-bis(1H-benzo[d]imidazol-2-ylthio)propane 10 [17] (Scheme 5). The ${ }^{1} \mathrm{H}-\mathrm{NMR}$ spectrum of the synthesized compound showed the presence of a methylene group at $\delta 3.25$ ppm connected with sulfur, another methylene group at $\delta 4.18 \mathrm{ppm}$ connected with nitrogen and the disappearance of signal belongs to NH. This confirmed that the alkylation occurred on the ring-sulfur that followed intramolecular cyclisation with the nitrogen atom of the same ring to give $\mathbf{9}$ and not with another ring to give 10. The structure of 9 was confirmed by the X-ray crystallography (Figure 2). It showed that one of the $\mathrm{CH}_{2}$ is out of the plane of the ring system. Thus, the envelope conformation is the one having the minimized energy structure.

Reaction of 1-(2-mercapto-1H-benzo[d]imidazol-1-yl)ethanone 2 with benzyl chloride in acetone as a solvent in the presence of triethylamine gave afford 2-(benzylthio)-1H-benzo[d]imidazole 13 (Scheme 6). The structure was confirmed from the spectral analysis [19]. Its IR spectrum showed the presence at $3400 \mathrm{~cm}^{-1}(\mathrm{NH})$, and did not show $\mathrm{C}=\mathrm{O}$ band. The ${ }^{1} \mathrm{H}-\mathrm{NMR}$ spectrum showed the presence of $\mathrm{NH}$ as a singlet at $\delta 12.56 \mathrm{ppm}$, and the $\mathrm{CH}_{2}$ as a singlet at $\delta 4.50 \mathrm{ppm}$. Its ${ }^{13} \mathrm{C}-\mathrm{NMR}$ spectrum showed the presence of $\mathrm{CH}_{2}$ as a signal at $\delta 30.5$, and the $\mathrm{C}=\mathrm{N}$ at $\delta 149.1 \mathrm{ppm}$. The 1-(2-(benzylthio)-1H-benzo[d]imidazol-1-yl)ethanone 12 was not obtained because the acetyl group was removed by the base. 


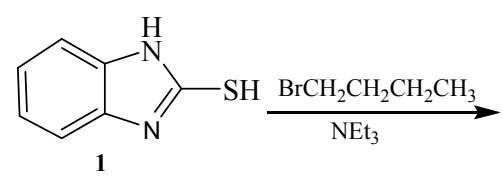<smiles>[I]=[Tl]</smiles><smiles>S=c1[nH]c2ccccc2[nH]1</smiles>

$1^{\prime}$ $\uparrow_{\mathrm{NEt}_{3}}$<smiles>CC(=O)n1c(=S)[nH]c2ccccc21</smiles>

2

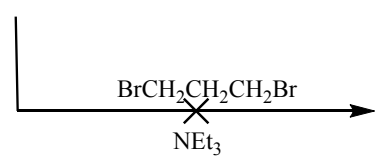<smiles>CCCCSc1nc2ccccc2[nH]1</smiles>

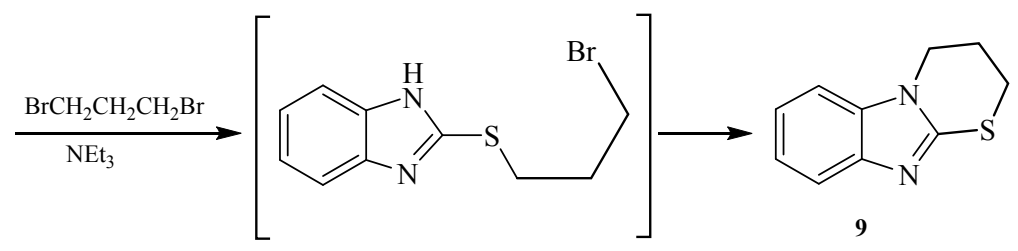<smiles>CC(=O)n1c(SCCCBr)nc2ccccc21</smiles>

10<smiles>CC(=O)Oc1nc2ccccc2n1SCCCSc1nc2ccccc2[nH]1</smiles>

11

Scheme 5. Synthesis of 3,4-dihydro-2H-[1,3]thiazino[3,2-a]benzimidazole 9.

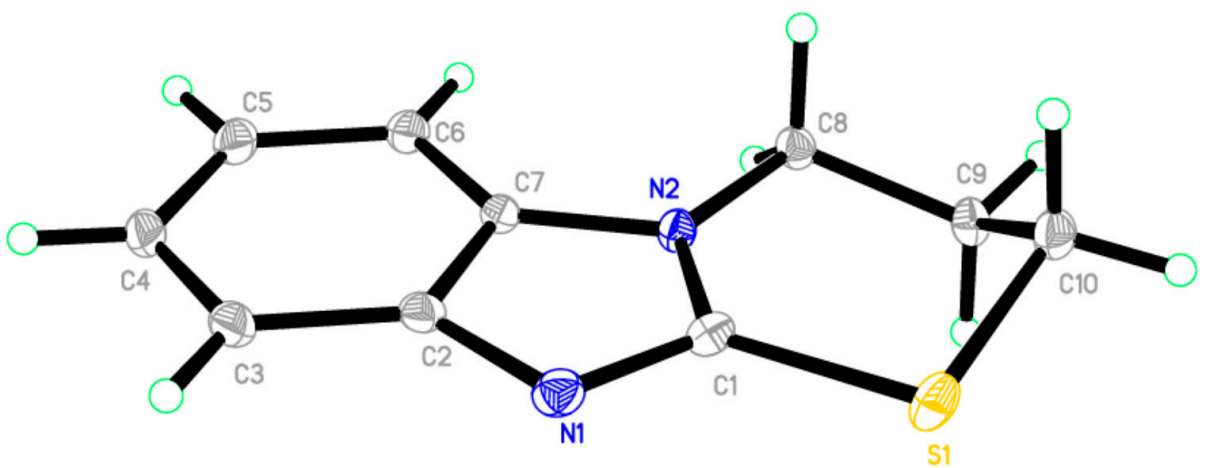

Figure 2. ORTEP diagram of the titled compound 9 drawn at 50\% ellipsoids for non-hydrogen atoms.<smiles>CC(=O)n1c(S)nc2ccccc21</smiles>

Scheme 6. Synthesis of 2-(benzylthio)- $1 H$-benzo[d]imidazole 13. 


\subsection{X-ray Single Crystal of $\mathbf{8}$ and $\mathbf{9}$}

The structures of compounds 8 and 9 were unambiguously deduced by single-crystal X-ray diffraction (Figures 1-4) technique. CCDC-1433060 and CCDC-1433059 contain the supplementary crystallographic data for this paper. These data can be obtained free of charge via http://www.ccdc. cam.ac.uk/conts/retrieving.html (or from the CCDC, 12 Union Road, Cambridge CB2 1EZ, UK; Fax: +44-1223-336033; E-mail: deposit@ccdc.cam.ac.uk. The structures were resolved by direct methods using the SHELXS97 program in the SHELXTL-plus package, and refined by a full-matrix least-squares procedure on $F^{2}$ using SHELXS97 [20]. Diffraction data were collected on a Bruker SMART APEXII CCD diffractometer (Bruker AXS Advanced X-ray Solutions GmbH, Karlsruhe, Germany). The crystal structure and refinement data of compounds $\mathbf{8}$ and $\mathbf{9}$ are listed in Table 1 . The selected bond distances and angles are presented in Tables 2-4. ORTEP drawings of final X-ray model of compounds 8 and 9 with the atomic numbering scheme are presented in Figures 1 and 2 while crystal packing presentation of compounds 8 and 9 are shown in Figures 3 and 4 respectively.

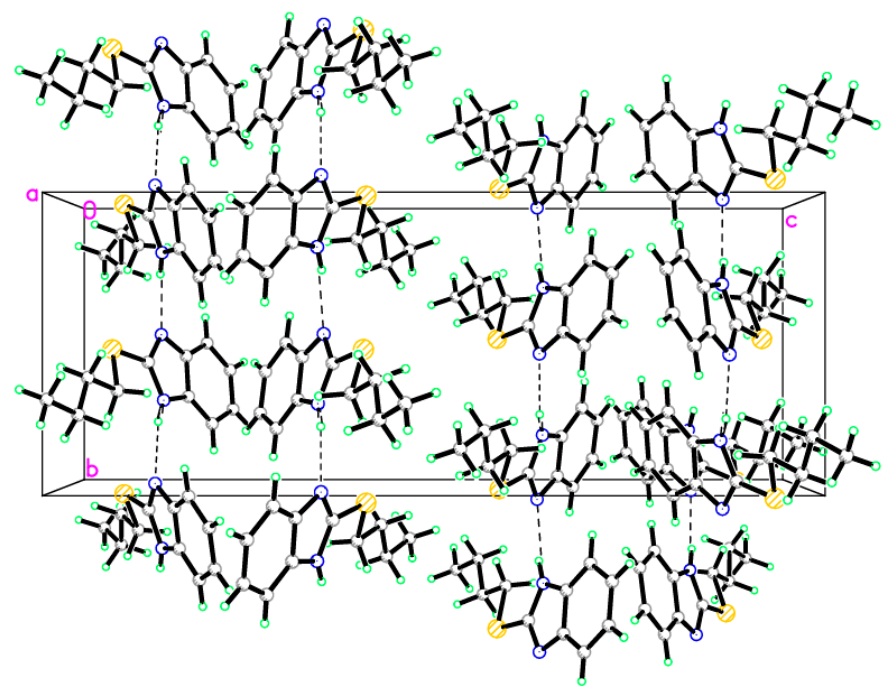

Figure 3. Crystal packing of compound 8 showing intermolecular hydrogen bonds as dashed lines along the $c$-axis.

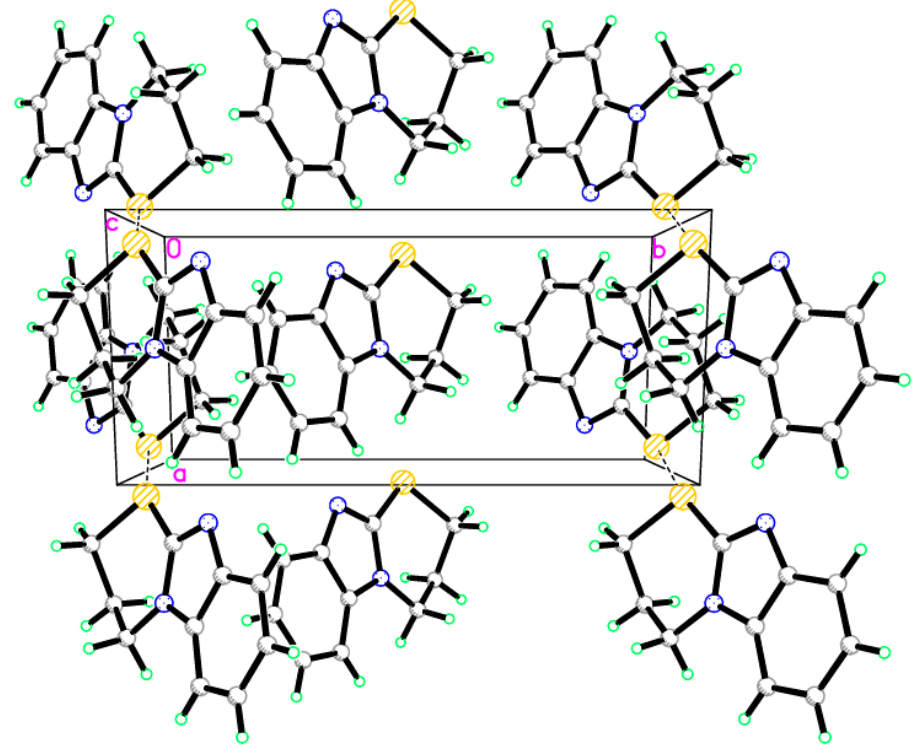

Figure 4. Crystal packing of compound 9, dotted lines are short S . S interactions. 
Table 1. The crystal and experimental data of compounds 8 and 9.

\begin{tabular}{ccc}
\hline Crystal Data & Compound 8 & Compound 9 \\
\hline Empirical formula & $\mathrm{C}_{11} \mathrm{H}_{14} \mathrm{~N}_{2} \mathrm{~S}$ & $\mathrm{C}_{10} \mathrm{H}_{10} \mathrm{~N}_{2} \mathrm{~S}$ \\
Formula weight & 206.30 & 190.27 \\
Temperature & $293 \mathrm{~K}$ & $293 \mathrm{~K}$ \\
Wavelength & $0.71073 \AA$ & $0.71073 \AA$ \\
Crystal system & Orthorhombic & Monoclinic \\
Space group & $P b c a$ & $P 2_{1} / c$ \\
a & $8.9060(4)$ & $6.0874(3)$ \\
b & $9.6531(4)$ & $12.3309(6)$ \\
c & $24.8720(13)$ & $12.4511(6)$ \\
$\beta$ & 90.00 & $110.087(3)$ \\
Volume & $2138.26(17)$ & $877.77(8)$ \\
$Z$ & 8 & 4 \\
Calculated density & $1.282 \mathrm{Mg} \cdot \mathrm{m}^{-3}$ & $1.440 \mathrm{Mg} \cdot \mathrm{m}^{-3}$ \\
Absorption coefficient & 0.26 & 0.32 \\
F $(000)$ & 880 & 400 \\
Crystal size & $0.38 \times 0.25 \times 0.22 \mathrm{~mm}$ & $0.68 \times 0.53 \times 0.40 \mathrm{~mm}$ \\
$\theta$ range & $2.8^{\circ}$ to $30.5^{\circ}$ & $2.4^{\circ}$ to $30.6^{\circ}$ \\
Reflections Collected & 3278 & 2691 \\
$\left(R_{\text {int }}\right)$ & 0.087 & 0.066 \\
$R_{1}$ with I $>2 \sigma(\mathrm{I})$ & 0.056 & 0.035 \\
$R_{2}$ with I $>2 \sigma(\mathrm{I})$ & 0.142 & 0.091 \\
Goodness of fit & 1.20 & 1.06 \\
max/min $\rho \mathrm{e} \AA$ & & \\
CCDC number & 0.77 and -0.29 & 0.42 and -0.33 \\
\hline & 1433060 & 1433059 \\
\hline & &
\end{tabular}

Table 2. Selected geometric parameters $\left(\AA,^{\circ}\right)$ of 8 .

\begin{tabular}{cccc}
\hline Bond Length or Angle & $\left(\mathbf{\AA}^{\circ}{ }^{\circ}\right)$ & Bond Length or Angle & $\left(\mathbf{A}^{\circ}{ }^{\circ}\right)$ \\
\hline S1-C7 & $1.7350(18)$ & N1-C7 & $1.365(2)$ \\
S1-C8 & $1.8070(19)$ & N2-C6 & $1.393(2)$ \\
N1-C1 & $1.385(2)$ & N2-C7 & $1.325(2)$ \\
C7-S1-C8 & $104.03(9)$ & N2-C6-C1 & $109.87(15)$ \\
C1-N1-C7 & $106.36(15)$ & S1-C7-N2 & $120.67(13)$ \\
C6-N2-C7 & $104.41(15)$ & N1-C7-N2 & $113.81(16)$ \\
N1-C1-C2 & $132.08(16)$ & S1-C7-N1 & $125.46(13)$ \\
N1-C1-C6 & $105.54(15)$ & S1-C8-C9 & $105.48(13)$ \\
N2-C6-C5 & $130.10(16)$ & & \\
\hline
\end{tabular}

Table 3. Hydrogen-bond geometry $\left(\AA,^{\circ}\right)$ of 8 .

\begin{tabular}{lcccl}
\hline $\mathbf{D}-\mathbf{H} \cdots \mathbf{A}$ & $\mathbf{D}-\mathbf{H}$ & $\mathbf{H} \cdots \mathbf{A}$ & $\mathbf{D} \cdots \mathbf{A}$ & $\mathbf{D}-\mathbf{H} \cdots \mathbf{A}$ \\
\hline $\mathrm{N} 1-\mathrm{H} 1 \mathrm{~N} 1 \cdots \mathrm{N} 2^{\mathrm{i}}$ & $0.86(3)$ & $2.07(3)$ & $2.886(2)$ & $159(3)$ \\
\hline \multicolumn{4}{c}{ Symmetry code: (i) $-\mathrm{x}+1 / 2, \mathrm{y}+1 / 2, \mathrm{z}}$. \\
\hline
\end{tabular}

Table 4. Selected geometric parameters $\left(\AA,^{\circ}\right)$ of 9 .

\begin{tabular}{cccc}
\hline Bond Length or Angle & $\left(\mathbf{A}^{\circ}{ }^{\circ}\right)$ & Bond Length or Angle & $\left(\mathbf{\AA}^{\circ}{ }^{\circ}\right)$ \\
\hline S1-C1 & $1.7402(11)$ & N2-C1 & $1.3700(16)$ \\
S1-C10 & $1.8174(12)$ & N2-C7 & $1.3850(14)$ \\
N1-C1 & $1.3226(15)$ & N2-C8 & $1.4654(15)$ \\
N1-C2 & $1.3925(15)$ & & \\
C1-N1-C2 & $104.02(10)$ & N1-C2-C3 & $130.19(11)$ \\
C1-N2-C7 & $105.90(9)$ & N1-C2-C7 & $110.22(10)$ \\
C1-N2-C8 & $128.83(9)$ & N2-C7-C2 & $105.67(10)$ \\
C7-N2-C8 & $125.04(10)$ & N2-C7-C6 & $131.10(11)$ \\
S1-C1-N1 & $122.49(9)$ & N2-C8-C9 & $111.91(10)$ \\
S1-C1-N2 & $123.29(8)$ & S1-C10-C9 & $111.49(8)$ \\
\hline
\end{tabular}




\section{Materials and Methods}

\section{General Methods}

The stated melting points are uncorrected and were performed on Gallenkamp melting point apparatus (Toledo, OH, USA). The purities of the compounds were checked by TLC using Merk Kieselgel 60-F254 plates (Darmstadt, Germany), and visually detected in an iodine chamber. The structures of the synthesized compounds were elucidated by using IR spectra on FT-IR (Shizmadu-series, Kyoto, Japan) using KBr disc technique at spectral laboratories in King Saud University. ${ }^{1} \mathrm{H}-\mathrm{NMR}$ spectra were determined with Jeol spectrometer (Tokyo, Japan) at $500 \mathrm{MHz}$ and expressed in $\delta$ units (ppm) relative to an internal standard of tetramethylsilane in solvent DMSO- $d_{6}$ at Alexandria University. ${ }^{13} \mathrm{C}-\mathrm{NMR}$ spectra were recorded with Jeol spectrometer at $125.7 \mathrm{MHz}$. The chemical shifts are expressed in $\delta(\mathrm{ppm})$ relative to the reference tetramethylsilane. The DMSO- $d_{6}$ was used as a solvent. Elemental analyses were performed at the micro-analytical laboratory at Cairo University, Egypt.

\section{1-(2-Thioxo-2,3-dihydro-1H-benzo[d]imidazol-1-yl)ethanone 2}

Acetic anhydride $(30 \mathrm{~mL}, 0.033 \mathrm{~mol})$ was added to $1 H$-benzo[d]imidazole-2(3H)-thione 1 (5 g, $0.033 \mathrm{~mol}$ ) and the stirred mixture was heated to $110-115^{\circ} \mathrm{C}$ for $30 \mathrm{~min}$. The solution was cooled then water $(150 \mathrm{~mL})$ was added, and finally kept for $30 \mathrm{~min}$ at room temperature. Colorless crystals were filtered off $(6.21 \mathrm{~g}, 97 \%$ Yield $) ; \mathrm{TLC}, \mathrm{R}_{\mathrm{f}}=0.773(1: 1, n$-hexane:ethyl acetate). The product was recrystallized from benzene to give white crystals. m.p. $201-202{ }^{\circ} \mathrm{C}$, (lit. [21] m.p., $\left.195{ }^{\circ} \mathrm{C}\right)$; IR $(\mathrm{KBr})$ v $1716(\mathrm{C}=\mathrm{O}), 1368\left(\mathrm{CH}_{3}\right), 2996$ ( $\mathrm{CH}$ aliphatic), and $3146\left(\mathrm{CH}\right.$ aromatic), $1591 \mathrm{~cm}^{-1}(\mathrm{C}=\mathrm{C}) .{ }^{1} \mathrm{H}-\mathrm{NMR}$ $\left(\mathrm{CDCl}_{3} / \mathrm{D}_{2} \mathrm{O}\right) \delta: 1.92\left(\mathrm{~s}, 3 \mathrm{H}, \mathrm{CH}_{3}\right), 7.19(\mathrm{~m}, 2 \mathrm{H}, \mathrm{Ar}-\mathrm{H})$, and $7.26 \mathrm{ppm}(\mathrm{m}, 2 \mathrm{H}, \mathrm{Ar}-\mathrm{H}) .{ }^{13} \mathrm{C}-\mathrm{NMR}$

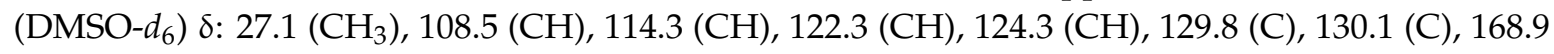
$(\mathrm{C}=\mathrm{S})$, and $171.1 \mathrm{ppm}(\mathrm{C}=\mathrm{O})$.

\section{1-(5,6-Dimethyl-2-thioxo-2,3-dihydro-1H-benzo[d]imidazol-1-yl)ethanone 4}

Acetic anhydride $(0.002 \mathrm{~mol}, 4 \mathrm{~mL})$ was added to $(0.002 \mathrm{~mol}, 0356 \mathrm{~g})$ of 5,6-dimethyl- $1 \mathrm{H}$ benzo[d]imidazole-2(3H)-thione 3 and the mixture was heated for $0.5 \mathrm{~h}$. The solution was cooled, stirred and poured onto water, and finally kept for $30 \mathrm{~min}$ at room temperature. Colorless sparkling crystals were filtered off $(0.39 \mathrm{~g}, 89 \%$ yield $), T L C, R_{f}=0.966(1: 1, n$-hexane:ethyl acetate). The product was recrystallized from ethanol, m.p. 258-259 ${ }^{\circ} \mathrm{C}$; IR $(\mathrm{KBr}) \vee 1685(\mathrm{~N}-\mathrm{C}=\mathrm{O}), 1627(\mathrm{C}=\mathrm{N}), 1506(\mathrm{C}=\mathrm{C})$, $3192 \mathrm{~cm}^{-1}$ (C-H aromatic). ${ }^{1} \mathrm{H}-\mathrm{NMR}\left(\mathrm{DMSO}-d_{6}\right) \delta: 2.22\left(\mathrm{~s}, 6 \mathrm{H}, 2 \mathrm{CH}_{3}\right), 2.94\left(\mathrm{~s}, 3 \mathrm{H}, \mathrm{CH}_{3}\right), 6.88(\mathrm{~s}, 1 \mathrm{H}$, $\mathrm{Ar}-\mathrm{H}), 7.76$ (s, 1H, Ar-H), and $13.14 \mathrm{ppm}(\mathrm{s}, 1 \mathrm{H}, \mathrm{NH}) .{ }^{13} \mathrm{C}-\mathrm{NMR}\left(\mathrm{DMSO}-d_{6}\right) \delta: 18.6\left(\mathrm{CH}_{3}\right), 18.9\left(\mathrm{CH}_{3}\right)$, $27.1\left(\mathrm{CH}_{3}\right), 109.0(\mathrm{CH}), 115.0(\mathrm{CH}), 128.2(\mathrm{C}), 130.7(\mathrm{C}), 132.9(\mathrm{C}), 168.4(\mathrm{C}=\mathrm{S})$, and $171.1 \mathrm{ppm}(\mathrm{C}=\mathrm{O})$. Calc. for $\mathrm{C}_{11} \mathrm{H}_{12} \mathrm{~N}_{2} \mathrm{OS}$ (220.29); C, 59.97; H, 5.49; N, 12.72\%, Found C, 59.66; H, 5.23; N, 12.43\%

Ethyl 2-(1H-benzo[d]imidazol-2-ylthio)acetate 5

A mixture of $1 H$-benzo[d]imidazole-2(3H)-thione $1(0.01 \mathrm{~mol}, 1.5 \mathrm{~g})$, in dry acetone $25 \mathrm{~mL}$ and potassium carbonate $(0.01 \mathrm{~mol}, 1.62 \mathrm{~g})$ was stirred and heated under reflux for $1 \mathrm{~h}$. Ethyl bromoacetate $(0.01 \mathrm{~mol}, 1.67 \mathrm{~g}, 1.1 \mathrm{~mL})$ was added to the reaction mixture and continuing stirring and heating for another $15 \mathrm{~h}$ until completion of the reaction. The reaction mixture was cooled then filtered off. Water was added to the filtrate and left at room temperature for $24 \mathrm{~h}$. The precipitate was filtered off and washed with water to give product, yield 77\%. It was recrystallized from ethanol to give white crystal, m.p. 97-98 ${ }^{\circ} \mathrm{C}$ (Lit. [18] m.p. 60-62 ${ }^{\circ} \mathrm{C}$, Lit. [15] m.p. $\left.117{ }^{\circ} \mathrm{C}\right), \mathrm{TLC}, \mathrm{R}_{\mathrm{f}}=0.554$ (1:1, n-hexane:ethyl acetate) IR (KBr) v $3457(\mathrm{NH}), 1507(\mathrm{NH}) \mathrm{IP}, 1739(\mathrm{C}=\mathrm{O}), 1269,1167(\mathrm{C}-\mathrm{O}), 3150$ (CH aromatic), and $1591 \mathrm{~cm}^{-1}(\mathrm{C}=\mathrm{C}) .{ }^{1} \mathrm{H}-\mathrm{NMR}\left(\mathrm{DMSO}-d_{6}\right) \delta: 1.13\left(\mathrm{t}, 3 \mathrm{H}, \mathrm{CH}_{3}\right), 4.09\left(\mathrm{q}, 2 \mathrm{H}, \mathrm{CH}_{2}\right), 4.18\left(\mathrm{~s}, 2 \mathrm{H}, \mathrm{CH}_{2}\right), 7.1$ $(\mathrm{s}, 2 \mathrm{H}, \mathrm{Ar}-\mathrm{H})$, and $7.40(\mathrm{~d}, 2 \mathrm{H}, \mathrm{Ar}-\mathrm{H}), 12.60 \mathrm{ppm}(\mathrm{s}, 1 \mathrm{H}, \mathrm{NH}) .{ }^{13} \mathrm{C}-\mathrm{NMR}\left(\mathrm{DMSO}-d_{6}\right) \delta: 13.2\left(\mathrm{CH}_{3}\right)$, $32.0\left(\mathrm{CH}_{2}\right), 60.4\left(\mathrm{CH}_{2}\right), 120.7(\mathrm{Ar}-\mathrm{C}), 148.3(\mathrm{C}=\mathrm{N})$, and $167.8 \mathrm{ppm}(\mathrm{C}=\mathrm{O})$. 
Diethyl 1,3-(2-thioxo-1H-benzo[d]imidazole-1,3(2H)-diyl)diacetate 6

A mixture of $1 H$-benzo[d]imidazole-2 $(3 \mathrm{H})$-thione $\mathbf{1}(0.01 \mathrm{~mol}, 1.5 \mathrm{~g})$, in dry acetone $(25 \mathrm{~mL})$ and triethylamine $(0.01 \mathrm{~mol}, 1.7 \mathrm{~mL})$ was stirred and heated under reflux for $1 \mathrm{~h}$. Ethylbromoacetate $(0.02 \mathrm{~mol}, 2.2 \mathrm{~mL})$ was added to the reaction mixture and continuing stirring and heating for another $19 \mathrm{~h}$ until completion of the reaction. The reaction mixture was cooled then filtered off. Water was added to the filtrate and left at room temperature for $24 \mathrm{~h}$ till precipitate was filtered off with water. The product was white powder, yield $76 \%$. It was recrystallized from ethanol. m.p. $199-201{ }^{\circ} \mathrm{C}$, TLC, $R_{\mathrm{f}}=0.722$ (1:1, n-hexane:ethyl acetate), IR (KBr) v $3457(\mathrm{NH}), 1507(\mathrm{NH}) \mathrm{IP}, 1739$ (C=O), 1220,

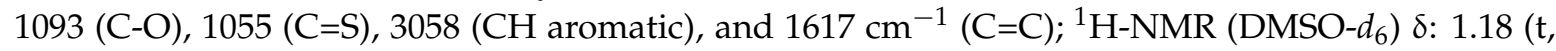
$\left.6 \mathrm{H}, 2 \mathrm{CH}_{3}\right), 4.14\left(\mathrm{q}, 4 \mathrm{H}, 2 \mathrm{CH}_{2}\right), 5.16\left(\mathrm{~s}, 4 \mathrm{H}, 2 \mathrm{CH}_{2}\right), 7.25(\mathrm{~m}, 2 \mathrm{H}, \mathrm{Ar}-\mathrm{H})$, and $7.47 \mathrm{ppm}(\mathrm{m}, 2 \mathrm{H}, \mathrm{Ar}-\mathrm{H})$. ${ }^{13} \mathrm{C}-\mathrm{NMR}\left(\mathrm{DMSO}-d_{6}\right) \delta: 13.1\left(2 \mathrm{CH}_{3}\right), 44\left(2 \mathrm{CH}_{2}\right), 60.4\left(2 \mathrm{CH}_{2}\right), 108.9(2 \mathrm{CH}), 122.3(2 \mathrm{CH}), 130.7(2 \mathrm{C}), 166.2$ $(2 \mathrm{C}=\mathrm{O})$, and $169.2 \mathrm{ppm}(\mathrm{C}=\mathrm{S})$. Calc. for $\mathrm{C}_{15} \mathrm{H}_{18} \mathrm{~N}_{2} \mathrm{O}_{4} \mathrm{~S}$ (322.38): $\mathrm{C}, 55.88 ; \mathrm{H}, 5.63 ; \mathrm{N}, 8.69 \%$. Found; $\mathrm{C}, 55.88 ; \mathrm{H}, 5.63 ; \mathrm{N}, 8.69 \%$.

\section{2-(Butylthio)-1H-benzo[d]imidazole 8}

To a stirred solution of 1-bromobutane $(0.005 \mathrm{~mol}, 0.54 \mathrm{~mL})$ in $10 \mathrm{~mL}$ of acetone was added a solution of 1-(2-mercapto-1H-benzo[d]imidazol-1-yl)ethanone $2(0.005 \mathrm{~mol}, 0.96 \mathrm{~g})$ in $40 \mathrm{~mL}$ acetone containing triethylamine $(0.01 \mathrm{~mol}, 1.4 \mathrm{~mL})$. The reaction mixture was stirred for $28 \mathrm{~h}$ at room temperature, then evaporated under vacuum, water was added to the precipitate, filtered off and the product $\left(0.64 \mathrm{~g}, 52 \%\right.$ yield); TLC, $\mathrm{R}_{\mathrm{f}}=0.601(1 ; 1, n$-hexane:ethyl acetate) and was crystallized from ethanol to give 2-(butylthio)-1H-benzo[d]imidazole 8, m.p. $135^{\circ} \mathrm{C}\left(135^{\circ} \mathrm{C}\right.$ lit. [19], 134-135 ${ }^{\circ} \mathrm{C}$ lit. [22]); IR (KBr) v $3400(\mathrm{NH}), 1671(\mathrm{C}=\mathrm{N}), 1619$ (NH-IP), $1588(\mathrm{C}=\mathrm{C}), 3047$ (CH-aromatic), 2955 (CH aliphatic), and 1498, 1465, $1432.7 \mathrm{~cm}^{-1}\left(\mathrm{CH}_{2}\right) .{ }^{1} \mathrm{H}-\mathrm{NMR}$ (DMSO- $\left.d_{6}\right) \delta: 0.85\left(\mathrm{t}, 3 \mathrm{H}, \mathrm{CH}_{3}\right), 1.37$ (sextet, $2 \mathrm{H}, \mathrm{CH}_{2}$ ), 1.63 (quint, $\left.2 \mathrm{H}, \mathrm{CH}_{2}\right), 3.23\left(\mathrm{t}, 2 \mathrm{H}, \mathrm{CH}_{2}\right), 7.06(\mathrm{~m}, 2 \mathrm{H}, \mathrm{Ar}-\mathrm{H}), 7.50(\mathrm{~s}, 2 \mathrm{H}, \mathrm{Ar}-\mathrm{H})$, and $12.50 \mathrm{ppm}(\mathrm{s}$, $\mathrm{IH}, \mathrm{NH}) .{ }^{13} \mathrm{C}-\mathrm{NMR}\left(\mathrm{DMSO}-d_{6}\right) \delta: 12.52\left(\mathrm{CH}_{3}\right), 20.3\left(\mathrm{CH}_{2}\right), 29.9\left(\mathrm{CH}_{2}\right), 30.4\left(\mathrm{CH}_{2}\right), 120.4(\mathrm{Ar})$, and 149.3 ppm (C=N). Calc. for: $\mathrm{C}_{11} \mathrm{H}_{14} \mathrm{~N}_{2} \mathrm{~S}$ (206.31); C, 64.04; H, 6.84; N, 13.58\%, Found C, 64.32; H, 6.34; $\mathrm{N}, 13.26 \%$.

\section{3,4-Dihydro-2H-[1,3]thiazino[3,2-a]benzimidazole 9}

A mixture of $1 H$-benzo[ $d$ ]imidazole-2(3H)-thione $1(0.026$ mole, $5 \mathrm{gm})$ in $60 \mathrm{~mL}$ ethanol and in presence of triethylamine $(0.01 \mathrm{~mol}, 1.39 \mathrm{~mL})$ was refluxed for $1 \mathrm{~h}$, then 1,3-dibromopropane $(0.013 \mathrm{~mol}$, $2.6 \mathrm{~g}$ ) was added. The reaction mixture was further heated under reflux for $5 \mathrm{~h}$. Then, ethanol was removed under vacuum, and water $(20 \mathrm{~mL})$ was added to the product, and kept for $24 \mathrm{~h}$ at room temperature to give white crystals. The product ( $4.68 \mathrm{~g}, 83 \%$ yield), was recrystallized from ethanol, TLC, $\mathrm{R}_{\mathrm{f}}=0.382\left(1: 1, n\right.$-hexane:ethyl acetate), m.p. $201-202{ }^{\circ} \mathrm{C} .{ }^{1} \mathrm{H}-\mathrm{NMR}$ (DMSO- $\left.d_{6}\right) \delta: 2.29(\mathrm{~m}, 2 \mathrm{H}$, $\left.\mathrm{CH}_{2}\right), 3.26\left(\mathrm{t}, 2 \mathrm{H}, \mathrm{CH}_{2}\right), 4.17\left(\mathrm{t}, 2 \mathrm{H}, \mathrm{CH}_{2}\right), 7.11(\mathrm{~m}, 2 \mathrm{H}, \mathrm{Ar}-\mathrm{H})$, and $7.39 \mathrm{ppm}(\mathrm{m}, 2 \mathrm{H}, \mathrm{Ar}-\mathrm{H}) .{ }^{13} \mathrm{C}-\mathrm{NMR}$ $\left(\mathrm{DMSO}_{6}\right)$ ) $8: 21.9\left(\mathrm{CH}_{2}\right), 24.3\left(\mathrm{CH}_{2}\right), 41.7\left(\mathrm{CH}_{2}\right), 107.9(\mathrm{CH}), 116.1(\mathrm{CH}), 120.02(\mathrm{CH}), 120.94(\mathrm{CH})$, 134.69 (C), 134.81 (C), 141.4; 145.75 ppm (C=N). Calc. for $\mathrm{C}_{10} \mathrm{H}_{10} \mathrm{~N}_{2} \mathrm{~S}$ (190.26): C, 63.13; H, 5.30; N, 14.72\%. Found: C, 63.42; H, 5.11; N, 14.41\%.

\section{2-(Benzylthio)-1H-benzo[d]imidazole 13}

To a stirred solution of benzyl chloride $(0.005 \mathrm{~mol}, 0.57 \mathrm{~mL})$ in $10 \mathrm{~mL}$ of acetone was added a solution of 1-(2-mercapto-1H-benzo[d]imidazol-1-yl)ethanone $(0.005 \mathrm{~mol}, 0.96 \mathrm{~g})$ in $40 \mathrm{~mL}$ acetone containing triethylamine $(0.01 \mathrm{~mol}, 1.39 \mathrm{~mL})$. The reaction mixture was stirred for $30 \mathrm{~h}$ at room temperature, then evaporated under vacuum, water was added to the precipitate, filtered off and the product $\left(0.4 \mathrm{~g}, 74 \%\right.$ yield), TLC, $\mathrm{R}_{\mathrm{f}}=0.644$ (1:1, $n$-hexane: ethyl acetate) was recrystallized from ethanol to give 2-(benzylthio)- $1 H$-benzo[d]imidazole, m.p. $185-186^{\circ} \mathrm{C}$ (lit. [19] m.p. $184^{\circ} \mathrm{C}$, lit. [23]. m.p. $\left.184-185^{\circ} \mathrm{C}\right)$; IR (KBr) v $3400(\mathrm{NH}), 1585$ (NH-IP), $1453\left(\mathrm{CH}_{2}\right), 2963$ (CH aliphatic), $3070(\mathrm{CH}$ aromatic), and 1610, $1515 \mathrm{~cm}^{-1}(\mathrm{C}=\mathrm{C}) .{ }^{1} \mathrm{H}-\mathrm{NMR}$ (DMSO- $\left.d_{6}\right) ; \delta: 4.50\left(\mathrm{~s}, 2 \mathrm{H}, \mathrm{CH}_{2}\right), 7.08(\mathrm{~m}, 2 \mathrm{H}$. Ar-H), 
$7.21(\mathrm{t}, 1 \mathrm{H}, \mathrm{Ar}-\mathrm{H}), 7.30$ (t, 2H, Ar-H), and 7.41-7.51 ppm (bd, 4H, Ar-H). ${ }^{13} \mathrm{C}-\mathrm{NMR}$ (DMSO- $\left.d_{6}\right) ; 8: 30.5$ $\left(\mathrm{CH}_{2}\right), 120.8(\mathrm{CH}), 126.7(\mathrm{CH}), 127.9(\mathrm{CH}), 128.2(\mathrm{CH}), 137.0(\mathrm{C})$, and $149.1 \mathrm{ppm}(\mathrm{C}=\mathrm{N})$.

\section{Conclusions}

The benzimidazole ring has been considered a pharmacophore ring. It has active centers that can be modified by some chemical reactions such as alkylation and acetylation to provide compounds of potential biological activity. The alkylation of $1 H$-benzo[d]imidazole-2(3H)-thione with dibromopropane did not give the respective alkylated derivatives 2-(3-bromopropylthio)- $1 \mathrm{H}$ benzo[d]imidazole or 1,3-bis(1H-benzo[d]imidazol-2-ylthio)propane, but gave 3,4-dihydro- $2 \mathrm{H}$ $[1,3]$ thiazino[3,2-a]benzimidazole. The formation of the last tricyclic ring indicated that the alkylation that occurred on the ring-sulfur atom was followed by intramolecular cyclisation with the nitrogen atom of the benzimidazole ring. This was confirmed by the X-ray crystallography. Alkylation of benzimidazole thione and its acetyl derivative gave the corresponding $S$-alkylated products, and in some cases a deacetylation process has been occurred. In the case of using ethyl bromacetate, it gave $\mathrm{S}$-mono- or $\mathrm{S}$-, $\mathrm{N}$-dialkylated derivatives depending on the ratio of the molar equivalents of the reactants. Deacetylation of acetyl benzimidazolethione derivative by different bases gave the imidazole thione, together with the starting acetyl-benzimidazolethione. However, increasing time caused a gradual change in their ratio till complete conversion to the deacetylated derivative. Both $1 H$-benzo[d]imidazole-2(3H)-thione and 5,6-dimethyl- $1 H$-benzo[d]imidazole-2(3H)-thione can exhibit tautomerism, and it has also been proven that the compounds in the solid state and in solution exist in the thione form, as confirmed by ${ }^{1} \mathrm{H}-\mathrm{NMR}$ spectra.

Acknowledgments: The authors would like to extend their sincere appreciation to the Deanship of Scientific Research at King Saud University for funding this Research group NO (RGP-1436-038).

Author Contributions: E.S.H.E.A. and Y.E.K. conceived and designed the experiments; N.A.-Q. performed the experiments; E-S.H.E.-A., Y.E.K. and N.M.N. analyzed the data; A.B., H.A.G. and H.-K.F. contributed reagents/materials/analysis tools; and E.-S.H.E.-A. wrote the paper.

Conflicts of Interest: The authors declare no conflict of interest.

\section{References}

1. Berg, D.; Büchel, K.H.; Plempel, M.; Zywietz, A. Action mechanisms of cell-division-arresting benzimidazoles and of sterol biosynthesis-inhibiting imidazoles, 1,2,4-triazoles, and pyrimidines. Mycoses 1986, 29, 221-229. [CrossRef]

2. Saimot, A.; Cremieux, A.; Hay, J.; Meulemans, A.; Giovanangeli, M.; Delaitre, B.; Coulaud, J. Albendazole as a potential treatment for human hydatidosis. Lancet 1983, 322, 652-656. [CrossRef]

3. Chimirri, A.; Grasso, S.; Monforte, A.; Monforte, P.; Zappala, M. Anti-HIV agents. I: Synthesis and in vitro anti-HIV evaluation of novel $1 H, 3 H$-thiazolo [3,4- $a$ ] benzimidazoles. Farmaco 1991, 46, 817-823. [PubMed]

4. Niemegeers, C.; Awouters, F.; Janssen, P. The pharmacological profile of a specific, safe, effective and non-sedative anti-allergic, astemizole. Agents Actions 1986, 18, 141-144. [CrossRef] [PubMed]

5. Iemura, R.; Hori, M.; Ohtaka, H. Syntheses of the metabolites of 1-(2-ethoxyethyl)-2-(hexahydro4-methyl-1H-1,4-diazepin-1-yl)-1H-benzimidazole difumarate (KG-2413) and related compounds. Chem. Pharm. Bull. 1989, 37, 962-966. [CrossRef] [PubMed]

6. Benavides, J.; Schoemaker, H.; Dana, C.; Claustre, Y.; Delahaye, M.; Prouteau, M.; Manoury, P.; Allen, J.; Scatton, B.; Langer, S. In vivo and in vitro interaction of the novel selective histamine H1 receptor antagonist mizolastine with $\mathrm{H} 1$ receptors in the rodent. Arzneim. Forsch. 1995, 45, 551-558.

7. Ishihara, K.; Ichikawa, T.; Komuro, Y.; Ohara, S.; Hotta, K. Effect on gastric mucus of the proton pump inhibitor leminoprazole and its cytoprotective action against ethanol-induced gastric injury in rats. Arzneim. Forsch. 1994, 44, 827-830.

8. Graham, D.Y.; McCullough, A.; Sklar, M.; Sontag, S.J.; Roufail, W.M.; Stone, R.C.; Bishop, R.H.; Gitlin, N.; Cagliola, A.J.; Berman, R.S. Omeprazole versus placebo in duodenal ulcer healing. Dig. Dis. Sci. 1990, 35, 66-72. [CrossRef] [PubMed] 
9. Piazzesi, G.; Morano, I.; Rüegg, J. Effect of sulmazole and pimobendan on contractility of skinned fibres from frog skeletal muscle. Arzneim. Forsch. 1987, 37, 1141-1143.

10. Wiedemann, I.; Peil, H.; Justus, H.; Adamus, S.; Brantl, V.; Lohmann, H. Pharmacokinetics of adimolol after single and multiple dose administration in healthy volunteers. Arzneim. Forsch. 1984, 35, 964-969.

11. Kubo, K.; Kohara, Y.; Imamiya, E.; Sugiura, Y.; Inada, Y.; Furukawa, Y.; Nishikawa, K.; Naka, T. Nonpeptide angiotensin II receptor antagonists. Synthesis and biological activity of benzimidazolecarboxylic acids. J. Med. Chem. 1993, 36, 2182-2195. [CrossRef] [PubMed]

12. Janssen, P.; Niemegeers, C.; Schellekens, K.; Dresse, A.; Lenaerts, F.; Pinchard, A.; Schaper, W.; van Nueten, J.; Verbruggen, F. Pimozide, a chemically novel, highly potent and orally long-acting neuroleptic drug. I. The comparative pharmacology of pimozide, haloperidol, and chlorpromazine. Arzneim. Forsch. 1968, 18, 261-279.

13. El Ashry, E.S.; Aly, A.A.; Aouad, M.R.; Amer, M.R. Revisit to the reaction of $o$-phenylene diamine with thiosemicarbazide to give benzimidazole-2-thione rather than benzotriazine-2-thione and its glycosylation. Nucleosides Nucleotides Nucleic Acids 2010, 29, 698-706. [CrossRef] [PubMed]

14. Bakavoli, M.; Seresht, E.R.; Rahimizadeh, M. Reinvestigation of $o$-phenylenediamine thermal cyclocondensation with thiosemicarbazide. Heterocycl. Commun. 2006, 12, 273-274. [CrossRef]

15. Elrayess, R.A.; Ghareb, N.; Azab, M.M.; Said, M.M. Synthesis and antimicrobial activities of some novel benzimidazole and benzotriazole derivatives containing $\beta$-lactam moiety. Life Sci. J. 2013, 10, 1784-1793.

16. Form, G.; Raper, E.; Downie, T. The crystal and molecular structure of 2-mercaptobenzimidazole. Acta Cryst. 1976, B32, 345-348. [CrossRef]

17. Lubenets, V.; Stadnitskaya, N.; Novikov, V. Synthesis of thiosulfonates belonging to quinoline derivatives. Russ. J. Electrochem. 2000, 36, 851-853. [CrossRef]

18. Shingalapur, R.V.; Hosamani, K.M.; Keri, R.S.; Hugar, M.H. Derivatives of benzimidazole pharmacophore: Synthesis, anticonvulsant, antidiabetic and DNA cleavage studies. Eur. J. Med. Chem. 2010, 45, 1753-1759. [CrossRef] [PubMed]

19. Narkhede, H.; More, U.; Dalal, D.; Mahulikar, P. Solid supported synthesis of 2-mercaptobenzimidazole derivatives using microwaves. J. Sci. Ind. Res. 2008, 67, 374-376.

20. Sheldrick, G.M. Shelxs 97, Program for the Solution of Crystal Structure; University of Göttingen: Göttingen, Germany, 1997.

21. Parras, F.; Guerrero, M.D.C.; Bouza, E.; Blázquez, M.J.; Moreno, S.; Menarguez, M.C.; Cercenado, E. Comparative study of mupirocin and oral co-trimoxazole plus topical fusidic acid in eradication of nasal carriage of methicillin-resistant Staphylococcus aureus. Antimicrob. Agents Chemother. 1995, 39, 175-179. [CrossRef] [PubMed]

22. Saxena, D.; Khajuria, R.; Suri, O. Synthesis and spectral studies of 2-mercaptobenzimidazole derivatives 1. J. Heterocycl. Chem. 1982, 19, 681-683. [CrossRef]

23. Suri, O.; Khajuria, R.; Saxena, D.; Rawat, N.; Atal, C. Synthesis and spectral studies of 2-mercaptobenzimidazole derivatives 2. J. Heterocycl. Chem. 1983, 20, 813-814. [CrossRef]

Sample Availability: Samples of the compounds 2-13 are available from the authors.

(C) 2015 by the authors; licensee MDPI, Basel, Switzerland. This article is an open access article distributed under the terms and conditions of the Creative Commons by Attribution (CC-BY) license (http://creativecommons.org/licenses/by/4.0/). 